\title{
Disseminated Eruptive Giant Mollusca Contagiosa in an Adult Psoriasis Patient during Efalizumab Therapy
}

\author{
Peter Weisenseel Alexander Vasilevic Kuznetsov Michael Flaig Jörg Christoph Prinz \\ Department of Dermatology, Ludwig Maximilian University, Munich, Germany
}

\section{Key Words}

Efalizumab - Mollusca contagiosa .

Biological agent $\cdot$ Psoriasis

\begin{abstract}
Molluscum contagiosum is a common viral skin infection in children with atopic diathesis and not rare in HIV patients. We report a 45-year-old psoriasis patient who developed eruptive mollusca contagiosa during an antipsoriatic treatment with efalizumab.
\end{abstract}

Copyright $\odot 2008$ S. Karger AG, Basel

\section{Case Report}

We report a 45-year-old female patient who was referred to our department because of a psoriasis flare-up and the development of skin papules following retreatment with efalizumab. She had been suffering from recalcitrant psoriasis vulgaris for 20 years and had a long history of different treatment modalities including extensive (repeat) UV therapy and therapy with fumaric acid esters. Complete remission was achieved after efalizumab $1 \mathrm{mg} /$ $\mathrm{kg} /$ week s.c. had been administered for 12 weeks. After the remission had been sustained by efalizumab treatment for another 3 months, the drug was discontinued on advice of the physician. Two months later, the patient had a severe psoriasis relapse and the efalizumab treatment regimen was resumed. Three weeks later, eruptive whitish papules occurred on the face and neck of the patient. The papules increased in number and size and were resistant to topical application of steroids and vitamin $\mathrm{D}$ analoga. Simultaneously, the psoriasis flared up. The patient presented at our department with more than 50 fleshcoloured partly umbilicated papules and nodules of up to $1 \mathrm{~cm}$ in diameter (fig. 1) that were diagnosed as disseminated giant mollusca contagiosa (MC).

Laboratory routine parameters, including complete blood cell count, blood chemistry and urine analysis, were unremarkable except for a minor acidocytosis. An HIV test was negative.

Histopathology of a nodule (shave biopsy, fig. 2) showed an exophytic tumour with epidermal hyperplasia and central impression forming a pouch containing keratinocytes filled with clustered intracellular deposits.

\section{Therapy and Outcome}

Efalizumab treatment was interrupted; a therapy with methotrexate $15 \mathrm{mg}$ once a week as well as narrow-band UVB treatment was initiated sparing the MC-affected regions. The MC were gradually removed with a pair of forceps. After some minor relapses, a complete and stable remission of the MC was achieved. The psoriasis was kept under control.

\section{Comment}

MC is a common epidermotropic pox virus infection in children. The virus is transferred by direct skin contact. In patients with regular immune function, the virus induces an effective antiviral response which prevents the manifestation of $\mathrm{MC}$ or leads to a complete remission of MC. As contact with the virus and mounting of a virus-specific immune response usually occur during childhood, MC infections are rarely found in adults. Predisposing factors in adults with MC are atopic dermatitis and a suppressed immune system. MC infections are therefore common in patients with HIV infection or transplant patients.

In contrast to patients with atopic dermatitis, psoriasis patients hardly experience bacterial or viral skin infections. The low rate of skin infections in psoriasis patients is attributed to the activation of antimicrobial defence mechanisms in inflamed skin. However, immunosuppressive systemic antipsoriatic therapy can predispose patients to skin infections. Accordingly, MC has been reported in psoriasis patients during immunosuppressive therapy such as methotrexate [1] or during infliximab treatment in combination with other immunosuppressive drugs [2,3].

Efalizumab is a CD11a antibody approved for the treatment of recalcitrant moderate to severe psoriasis vulgaris. Efalizumab inhibits T-cell activation and par-

\section{KARGER}

Fax +41 613061234

E-Mail karger@karger.ch

www.karger.com
(C) 2008 S. Karger AG, Basel

$1018-8665 / 08 / 2171-0085 \$ 24.50 / 0$

Accessible online at:

www.karger.com/drm
Dr. Peter Weisenseel, MD

Department of Dermatology, Ludwig Maximilian University

Frauenlobstrasse 9-11, DE-80337 Munich (Germany)

Tel. +49 8951606010, Fax +498951606312

E-Mail peter.weisenseel@med.uni-muenchen.de 

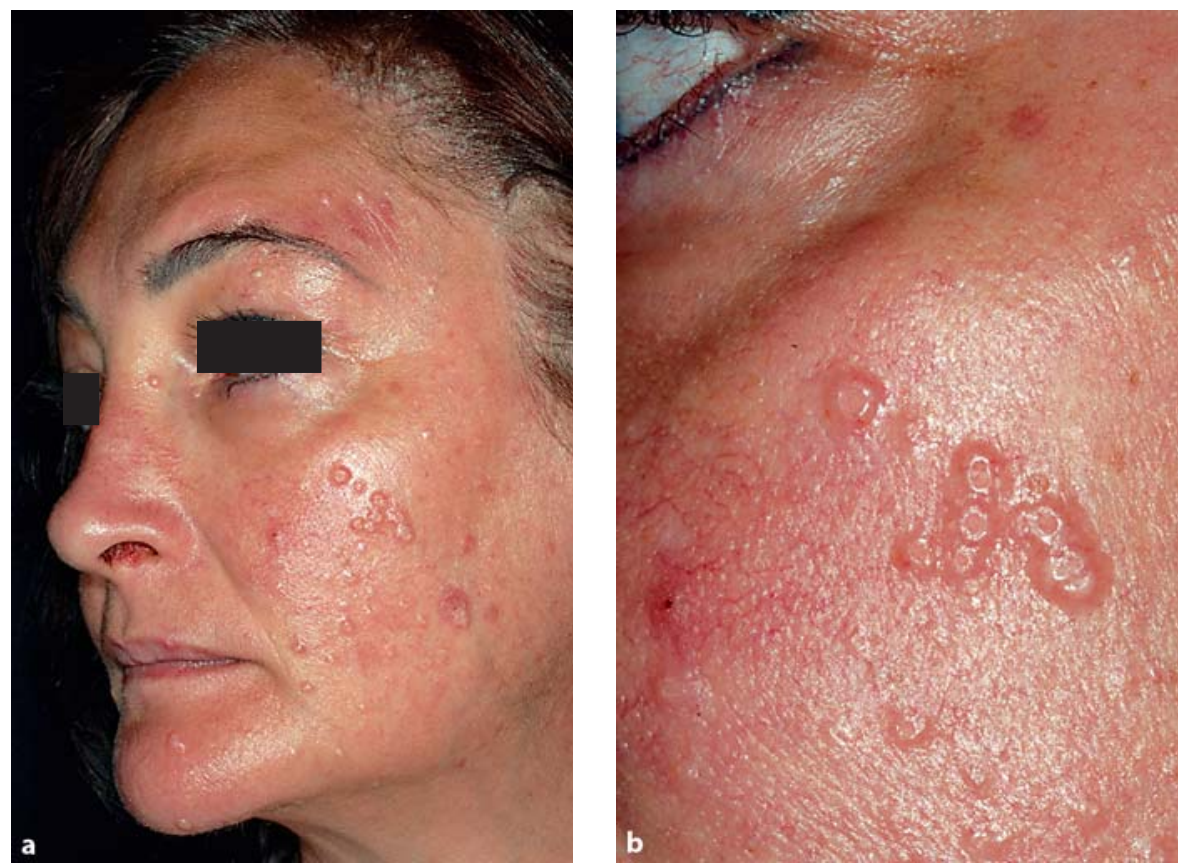

Fig. 1. a Umbilicated papules and nodules on the face and neck. b Detail, left cheek.

ticularly T-cell transmigration from blood vessels into the skin [4]. The rate of infections or malignant tumours during efalizumab treatment for psoriasis vulgaris is generally not increased $[5,6]$. Therefore, efalizumab is considered as a safe longterm treatment regimen.

The exacerbation of MC under efalizumab therapy reported here might indicate that under certain conditions efali- zumab might assist viral infections to develop and defeat the immune system. While MC lesions in childhood normally measure 1-4 $\mathrm{mm}$, giant-shaped $\mathrm{MC}$ of more than $5 \mathrm{~mm}$ in diameter can be found in HIV-positive patients and patients under immunosuppressive therapy [7]. Although case reports provide only little evidence in general, they may prove necessary to raise the awareness of unantici-

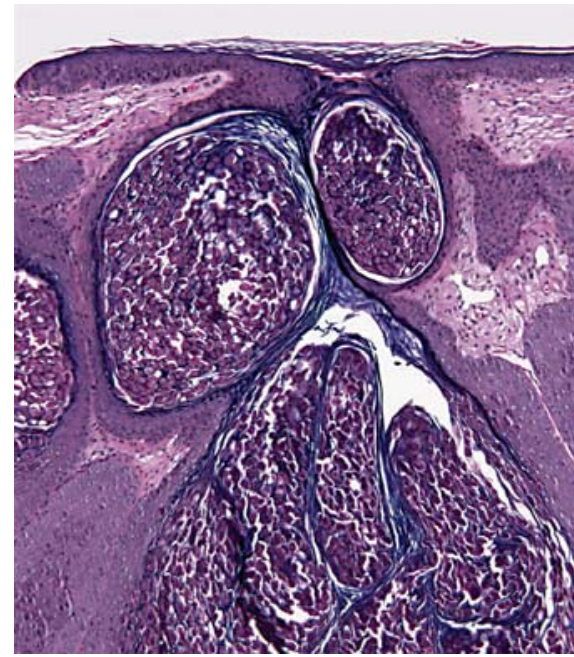

Fig. 2. Histology - exophytic tumour with epidermal hyperplasia and central impression forming a pouch containing keratinocytes filled with clustered intracellular deposits.

pated adverse events in this new class of psoriasis drugs. This first published case of MC during efalizumab treatment demonstrates that biological agents do not only offer new and effective treatment options for chronic inflammatory diseases, but may also confront us with atypical or unexpected infections.

\section{References}

1 Lim KS, Foo CC: Disseminated molluscum contagiosum in a patient with chronic plaque psoriasis taking methotrexate. Clin Exp Dermatol 2007;32:591-593.

2 Wachi K, Prasertsuntarasai T, Kishimoto M, Uramoto K: T-cell lymphopenia associated with infliximab and cyclophosphamide. Am J Med Sci 2005;330:48-51.

3 Cursiefen C, Grunke M, Dechant C, Antoni C, Jünemann A, Holbach LM: Multiple bilateral eyelid molluscum contagiosum lesions associated with TNFalpha-antibody and methotrexate therapy. Am J Ophthalmol 2002; 134:270-271.
4 Jullien D, Prinz JC, Langley RG, Caro I, Dummer W, Joshi A, Dedrick R, Natta P: Tcell modulation for the treatment of chronic plaque psoriasis with efalizumab (Raptiva): mechanisms of action. Dermatology 2004; 208:297-306.

5 Papp KA, Camisa C, Stone SP, Caro I, Wang $\mathrm{X}$, Compton P, Walicke PA, Gottlieb AB: Safety of efalizumab in patients with moderate to severe chronic plaque psoriasis: review of clinical data. Part II. J Cutan Med Surg 2005;9:313-323.
6 Leonardi CL, Toth D, Cather JC, Langley RG, Werther W, Compton P, Kwon P, Wetherill G, Curtin F, Menter A: Review of malignancies observed during efalizumab (Raptiva ${ }^{\circledR}$ ) clinical trials for plaque psoriasis. Dermatology 2006;213:204-214.

7 Vozmediano JM, Manrique A, Petraglia S, Romero MA, Nieto I: Giant molluscum contagiosum in AIDS. Int J Dermatol 1996;35: 45-47. 